\title{
Outbreak of tularaemia in central Norway, January to March 2011
}

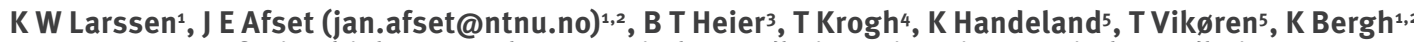

1. Department of Microbiology, St Olavs Hospital, Trondheim University Hospital,Trondheim, Norway

2. Department of Laboratory Medicine, Children's and Women's Health, Norwegian University of Science and Technology, Trondheim, Norway

3. Division of Infectious Disease Control, Norwegian Institute of Public Health, Oslo, Norway

4. Division of Environmental Medicine, Norwegian Institute of Public Health, Oslo, Norway

5. Norwegian Veterinary Institute, Oslo, Norway

Citation style for this article:

Larssen KW, Afset JE, Heier BT, Krogh T, Handeland K, Vikøren T, Bergh K. Outbreak of tularaemia in central Norway, January to March 2011. Euro Surveill. 2011;16(13):pii=19828. Available online: http://www.eurosurveillance.org/ViewArticle.aspx?Articleld=19828

From January to March 2011, 39 cases of tularaemia were diagnosed in three counties in central Norway: 21 cases of oropharyngeal type, 10 cases of glandular/ulceroglandular type, two of respiratory and two of typhoid type. Three cases were asymptomatic and clinical information was unavailable for one case. The mean age was 40.3 years (range $2-89$ years). Thirtyfour reported use of drinking water from private wells. An increased rodent (lemming) population and snow melting may have led to contamination of the wells with infected rodents or rodent excreta.

\section{Outbreak description}

From 1 January to 25 March 2011, 39 confirmed cases (16 female and 23 male) of tularaemia were reported from the counties of Sør-Trøndelag (28 cases), Møre og Romsdal ( 5 cases) and Nord-Trøndelag (6 cases) in central Norway. A confirmed case was defined as a person who had clinical symptoms compatible with tularaemia or had used drinking water from the same source as a previous case, and in whom Francisella tularensis infection was confirmed by a laboratory test as described below. The cases were geographically scattered within each county, involving 13 different municipalities (Figure), and were not linked to one common source. In comparison, seven cases were reported in total from other parts of the country in the same period. In 2009 and 2010 four and eight cases respectively were reported from central Norway.

Tularaemia is a zoonotic disease caused by the bacterium F. tularensis. Four F. tularensis subspecies are recognised: tularensis, holarctica, mediasiatica and novicida. In Europe, the infection is due to subspecies holarctica which causes in general less severe disease than subspecies tularensis, which is common in North America. Several vectors may be involved in transmitting the disease to humans, commonly rodents and hares, but infection may also be transmitted via insect bites [1].
Several clinical forms are recognised, with oropharyngeal and ulceroglandular disease being the most common clinical presentations in Norway [2]. Oropharyngeal disease is commonly associated with contaminated food and water, while ulceroglandular forms are more often seen when there has been skin contact with infected animals or after insect bites [3].

Outbreaks of oropharyngeal tularaemia have previously been reported from several European countries $[3,4]$. Tularaemia is a notifiable disease in Norway and during the past 10 years, three outbreaks were reported in Norway [5-7] and all were associated with water sources in areas where dead lemmings (Lemmus lemmus) had been observed previously. From 2001 to 2010 , between three and 66 cases of tularaemia were reported annually in the whole country, with an increase from 16 to 32 cases on average (data available from: www.msis.no). This increase may in part be explained by the outbreaks mentioned above.

\section{Diagnosis and clinical presentation}

In the outbreak described here, the most common clinical presentation was fever and pharyngitis (oropharyngeal type, 21 cases) and cervical lymphadenopathy (glandular/ulceroglandular type, 10 cases). Among the remaining eight tularaemia cases, two were classified as respiratory and two as typhoid type, while three were asymptomatic and clinical information was unavailable for one case.

The diagnosis was primarily established by serology (microagglutination and an in-house IgG/IgM Elisa) in 30 patients [8], by $F$. tularensis specific PCR analysis in seven patients [9] and by blood culture (BactAlert, BioMerieux) in two patients. The two bacterial isolates were verified as $F$. tularensis by PCR and sequencing of the $16 \mathrm{~S}$ rDNA gene, and confirmed as non-subspecies tularensis by $p d p A$ PCR [10]. 
Thirty-four of the 39 diagnosed cases had been drinking water from a private well or a stream. F. tularensis DNA was detected by PCR in filtered water from five different wells tested in Sør-Trøndelag. Seven cases in one municipality were linked to the same water source. Apart from that, only two cases have been confirmed to share a common well so far. Follow-up serology has been recommended for several of the persons exposed to some of the putative water sources.

\section{Discussion}

The current outbreak involves a large number of municipalities in three counties in central Norway. The clinical presentation with oropharyngeal tularaemia and cervical lymphadenopathy linked to the use of private wells in the winter season makes contaminated water the most likely source of infection in this outbreak. Detection of $F$. tularensis DNA by PCR analyses in some of the wells supports this assumption for some of the cases. Use of private wells is relatively common in rural areas of Norway although exact data on such use are not available.

The precise mechanism of contamination of the wells with $F$. tularensis is as yet unknown. However, November and December 2010 were unusually cold months, while in January 2011 temperatures increased leading to melting of snow and possible contamination of private wells by surface water contaminated with bacteria from rodent cadavers or rodent excreta. Since the incubation period for tularaemia may be up to three weeks, and time from symptoms until seroconversion might be up to six weeks, more cases may follow.

Tularaemia has traditionally been called both 'lemming fever' and 'hare plague' and this clearly indicates rodents and hares as transmitters of disease. Years with a great increase in the rodent population are seen with intervals of about three to four years [11] and in the summer and autumn of 2010, a high density of lemmings could be observed in the southern and central parts of Norway. Simultaneously, the Norwegian Veterinary Institute observed a wide geographical distribution of fatal cases of tularaemia in the mountain hare (Lepus timidus) in these regions [12]. The mountain hare is very susceptible to this infection and normally dies from septicaemia within a few days after exposure.

The use of small streams and private wells as a source of drinking water and for other purposes in rural areas of Norway is a matter of concern. In existing guidelines issued by the National Institute of Public Health the population is advised to boil drinking water and

\section{FIGURE}

Geographical distribution of confirmed cases of tularaemia in Norway, January to March $2011(\mathrm{n}=39)$

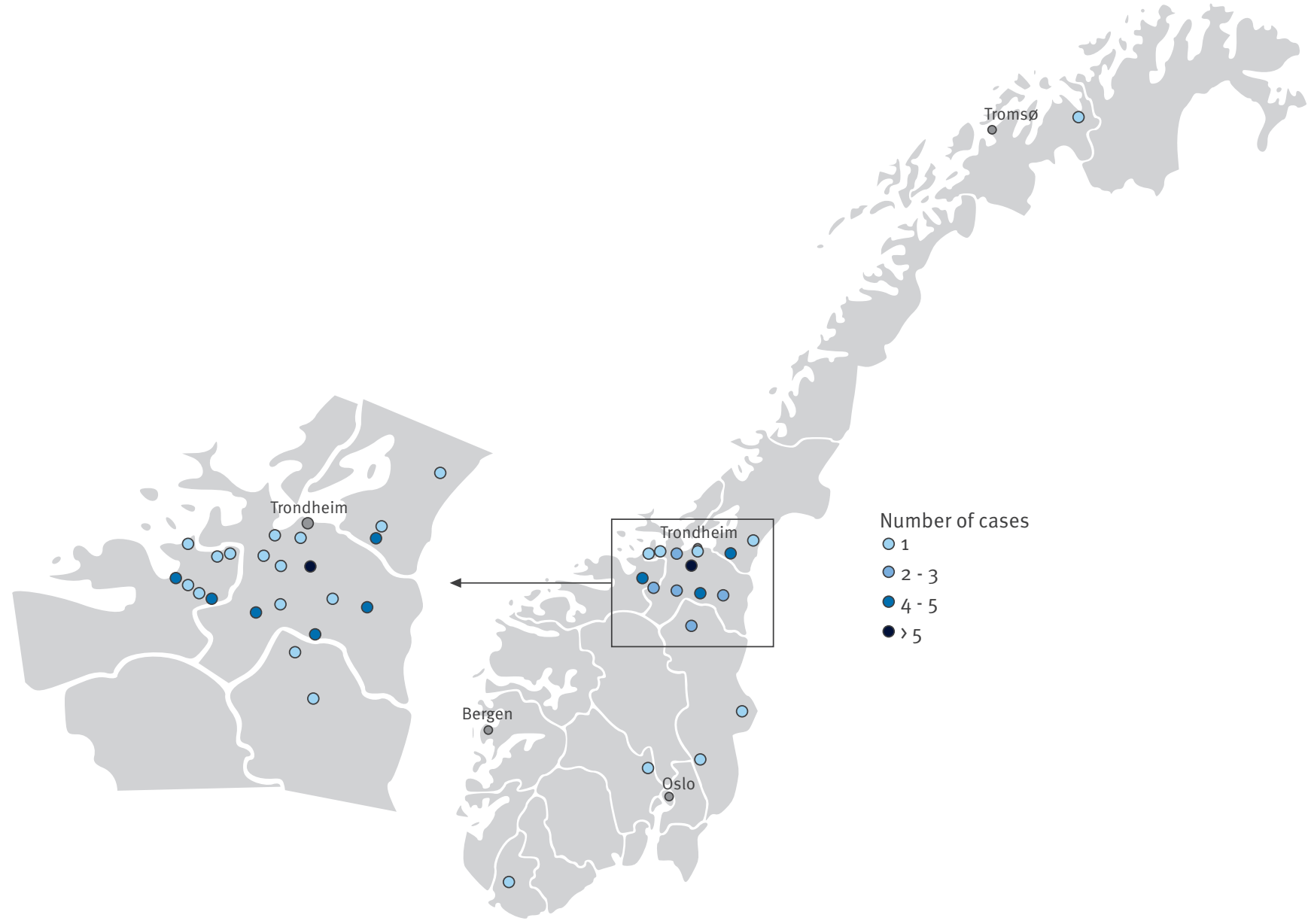


inspect the wells for dead rodents in case of suspected or confirmed cases of waterborne tularaemia. Every well owner should make the necessary effort to prevent small rodents from entering the well water by carefully covering every opening and plugging every small holes where the rodents can enter. It is also important to secure the well from contamination by surface water after snow melting. In case of proven or suspected contaminated wells, the water should be disinfected before further use. However, this may not be feasible for persons who use drinking water from a stream. The Norwegian Food Safety Authority has recently released information to the media and to the general public with similar advice and information in relation to the current outbreak. The local health authority in each municipality is responsible for instituting infection control measures including advice to the public and investigations of the putative drinking water sources.

\section{References}

1. World Health Organization (WHO) Epidemic and Pandemic Alert and Response. WHO guidelines on tularaemia. Geneva:WHO; 2007. Available from: http://www.who.int/csr/resources/ publications/WHO_CDS_EPR_2007_7.pdf

2. Brantsaeter AB. Twenty-five years of tularaemia in Norway, 1978-2002. Abstract number: 10.1111/j.1198-743X.2004.902 0142.x. European Society of Clinical Microbiology and Infectious Diseases. 14th European Congress of Clinical Microbiology and Infectious Diseases. Prague; 1-4 May 2004.

3. Tärnvik A, Priebe HS, Grunow R. Tularaemia in Europe: an epidemiological overview. Scand J Infect Dis. 2004:36(5):350-5.

4. Willke A, Meric M, Grunow R, Sayan M, Finke El, Splettstösser W, et al. An outbreak of oropharyngeal tularaemia linked to natural spring water. J Med Microbiol. 2009;58(Pt 1):112-6.

5. Rike HF, Vigerust A, Bergh K. Vannbårent utbrudd av tularemia (harepest) i Midtre Gauldal. [A waterborne outbreak of tularaemia in Midtre-Gauldal]. Norwegian Institute of Public Health. 27 Oct 2003. Norwegian. Available from: http://www. fhi.no/eway/default.aspx?pid=233\&trg=MainLeft 5669\& Main eft_5669=5544:27208::0:5667:1:::0:0

6. Brantsaeter AB, Krogh T, Radtke A, Nygard K. Tularaemia outbreak in northern Norway. Euro Surveill. 2007;12(13):pii=3165. Available from: http://www. eurosurveillance.org/ViewArticle.aspx?Articleld=3165

7. Melien P, Holsdal RE. Tularemi i Meldal - en vanskelig diagnose? [Tularaemia in Meldal- a difficult diagnosis?]. Norwegian Institute of Public Health. 18 Mar 2008. Norwegian. Available from: http://www.fhi.no/eway/default.aspx?pid $=233 \& \operatorname{trg}=$ Area $5626 \&$ MainArea $5661=5619: 0: 15,4427: 1$ 0:0:::0:0\&MainLeft_5619=5626:68396::1:5625:1:::0:0\&Ar ea_5626=5544:68400::1:5628:1:::0:0

8. Bevanger L, Maeland IA, Naess Al. Competitive enzyme immunoassay for antibodies to a 43,000-molecular-weight Francisella tularensis outer membrane protein in the diagnosis of tularemia. J Clin Microbiol. 1989;27(5):922-6.

9. Sjöstedt A, Erikson U, Berglund L, Tärnvik A. Detection of Francisella tularensis in ulcers of patients with tularaemia by PCR. J Clin Microbiol. 1997;35(5):1045-8.

10. Tomaso H, Scholz HC, Neubauer H, Al Dahouk S, Seibold E, Landt 0 , et al. Real-time PCR using hybridization probes for the rapid and specific identification of Francisella tularensis subspecies tularensis. Mol Cell Probes. 2007;21(1):12-6.

11. Semb-Johaansson A, Ims RA. Smågnagerne [Rodents]. SembJohansson A, Frislid R, editors. Oslo;1990. 121-71. Norwegian.

12. Norwegian Veterinary Institute. Flere tilfeller av harepest $i$ Sør-Norge [Severeal cases of tularaemia in South-Norway]. Norwegian Veterinary Institute. 25 Nov 2010. Norwegian. Available from: http://www.vetinst.no/index.php/nor/Nyheter/ Flere-tilfeller-av-harepest-i-Soer-Norge 